\title{
Pesticides Abuse and Health Implications in Ghana: A Review
}

\author{
Atta Kwesi Aidoo ${ }^{1}$, Stephen Arthur ${ }^{2}$, Grace Bolfrey - $\mathrm{Arku}^{3}$ and Moses \\ Brandford Mochiah ${ }^{4}$
}

\author{
CSIR - Crops Research Institute, P. O. Box 3785, Kumasi, Ghana \\ Corresponding Author: Stephen Arthur \\ Email: papakow86@gmail.com
}

\begin{abstract}
It is estimated that $25 \%$ of the globally produced pesticides are used in developing countries and African farmers use only 4\%. However, more than $90 \%$ of the global minimum of 300,000 death cases related to pesticides poisoning annually are believed to occur in developing countries. Efforts have been made worldwide to restrict or ban the use of persistent pesticides while regulating the use of other pesticides to ensure environmental and food safety. However, most pesticide dealers and users of many developing countries including Ghana have not come to terms with the associated safety practices that ensure a safe use to keep the integrity of our environment. Pesticide residues have been detected in food, water, water sediment, air, blood and human breastmilk because ofpesticide abuses. This paper reviews some abuse practices during handling and storage, application, or disposal; associated exposures; public health risks associated with the abuse practices; as well as issues of monitoring and enforcement. Some instances of casualties are also discussed.

Keyword-pesticide abuse, pesticide application, pesticide disposal, pesticide handling, pesticide residue.
\end{abstract}

\section{INTRODUCTION}

Global pesticides use was estimated at 2.26 megatonnes in 2001 and 2.4 megatonnes in 2006 and 2007. While 2.5 megatonnes is estimated to be used yearly in recent times, $40 \%$ is estimated to be herbicides, $17 \%$ insecticides and $10 \%$ fungicides (WHO, 2008; NPAS, 2012). According to WHO (2008), the use of pesticides has increased in developing countries with Africa, South and Central America, Asia and Eastern Mediterranean being the fastest growing pesticides markets. It is estimated that $25 \%$ of the global pesticides produced are used in developing countries and African farmers use only 4\% (WHO, 2008; NPAS, 2012). In Ghana, it is estimated that pesticides worth approximately 100 million dollars are imported annually (NPAS, 2012).

Though the amount of pesticides used in the developing world is relatively low, developing countries have higher pesticides risk due to abnormal exposure to pesticides resulting from abuse/misuse. Weaker links between healthcare as well as regulatory systems and pesticide dealers and users increases the impact and occurrences of the abuses (WHO, 2008). About 1-5 million pesticide poisoning cases are estimated to occur annually in the world, causing about 20,000 fatalities in agricultural workers, and a chunk of this is recorded in developing countries (WHO, 2004). Also, about $99 \%$ of the global minimum of 300,000 death cases related to pesticides poisoning annually are believed to occur in developing countries (WHO, 2008). Most authors attribute these happenings to pesticides use but a critical analysis of is sues points to the fact that pesticides misuse is the issue.

Rachel Carson in 1962 wrote the Silent Spring to raise public awareness on the effects of harmful pesticide use on our health and environment. Efforts have been made to restrict or barn the use of persistent pesticides while regulating the use of other pesticides to ensure environmental and food safety. However, most pesticide dealers and users of many developing countries have not come to terms with the associated safety practices that ensure a safe use to keep the integrity of our environment. Regulatory bodies have challenges that do not allow them to work efficiently on their mandate.

This paper is a review of some of the abuse/misuse practices, associated exposures, monitoring and law enforcement, and public health issues associated with pesticide abuses with some instances of casualties discussed. 


\section{COMMON ABUSE PRACTICES}

Some recorded and observed pesticides abuse/misuse practices have been discussed. These practices may be classified broadly under three main headings namely: pesticide handling and storage, application and pre - harvest observation, or disposal.

2.1 Pesticide handling and Storage

In many parts of Ghana and other Sub Saharan African countries, pesticide handling is one of the most important factors that makes its use dangerous (Clarke et al., 1997). Most pesticide sellers and farmers in Ghana are ignorant on properhandling of pesticides. Some pesticides sellers display their products in direct hot sunny conditions while others sit in pesticide stores and display rooms all day inhaling strong fumes of pesticides. Most sellers and farmers alike neither put on protective clothing nor wash after handling pesticides. Farmers store used or unused pesticides together with food in inappropriate places. According to Okoffo et al. (2016), $52 \%$ of cocoa farmers in the formerly Brong Ahafo Region store pesticides in their homes (bedrooms, storerooms, porches or on roofs). Clarke et al.(1997) also found out that almost $50 \%$ of farmers stored their pesticides in their homes with a lot of them storing them in their bedrooms. Mattah et al. (2015) also reported that $86 \%$ of farmers in the Greater Accra Region stored their pesticides at home. Considering data available since the $90 \mathrm{~s}$, it is obvious that not much has changed regarding how and where farmers store used or unused pesticides. In most communities, there have been numerous but unreported cases of children accidentally drinking pesticides because they were stored at home and in places that could be easily reached by children; and or the pesticides were not stored in their original containers (especially in water bottles). In 2010, it was reported in the Upper East Region that 15 farmers died of suspected pesticides poisoning as a result of poor storage of pesticides in their homes, the pesticides leaked into their food stock (NPAS, 2012). Applicators have confirmed experiencing symptoms indicative of the effect of poor handling of pesticides. Report on a survey conducted by the National Presbyterian Agricultural Services (NPAS, 2012) in 14 villages in the Upper East Region of Ghana indicated that a quarter or a third of 183 applicators confirmed inhaling or experiencing chemical spillage on their bodies respectively due to poor handling. Obviously, if the country can reduce risks of pesticide abuse and their effects on users, handling and storage are key areas to look at.

2.2 Abuses in pesticides application
In Ghana, most cocoa farmers and about $87 \%$ of vegetable farmers use pesticides (Okoffo et al., 2016; Dinham, 2003). Pesticides are also used extensively in the production of other commodities like cowpea, maize, rice, cassava, fruits etc. They are also used for pest control in the homes (Mattah et al., 2015). There are several avoidable pesticides application practices that result in greater risk to humans, other mammals, and the environment at large. Most farmers and applicators of pesticides (labourers) do not use adequate Personal Protective Equipment (PPEs). In a survey by Okoffo et al. (2016), it was revealed that while $45 \%$ of cocoa farmers partially used PPEs, $20 \%$ do not use PPEs at all during pesticides application. Most of these farmers used handkerchiefs or face towels in place of respirators, a practice not unique to only cocoa farmers. According to Mattah et al. (2015), less than 30\% of farmers generally use full PPEs. Dari et al. (2016) confirmed $80 \%$ of tomato farmers in the northern part of Ghana do not use PPEs during pesticides application. Also, in a survey in the Ashanti and Brong Ahafo Regions, it was confirmed that less than $20 \%$ of applicators used full PPEs (Afari-Sefa, 2015). These suggest that about $70 \%$ or more of farmers generally do not dress appropriately during pesticides application exposing part(s) of their bodies as entry points for pesticides. The phenomenon has been attributed to the fact that users complain of the discomfort they go through in using PPEs because of the hot and harsh weather condition in the tropics. To others, PPEs are expensive or unavailable; and yet with some others, they don't see the relevance or are ignorant of the benefits of using PPEs (Clarke et al., 1997). These are issues governments and researchers must find solutions to, because pesticide use has come to stay. Research may be needed to look for innovative ways of progressively providing comfortable but affordable and readily available PPE set for farmers in the tropics. A comprehensive plan may be needed to reach almost all farmers in the country to expose them to among other things the need to use protection during pesticide application. There exists also the use of nozzles meant for applying fungicides/insecticides for herbicide application and vice versa. Most farmers and applicators alike don't know much about drift, its effect and how to minimize it. Pesticides are applied close to water bodies while the maximum number of times a pesticide can be applied in the growing season on the same field is exceeded (Asante and Ntow, 2009). Some farmers still apply banned, expired, overdose, or pesticides not registered by the EPA. Some also use pesticides on crops they are not registered for (example is the use of pesticides strictly supplied for use in 
cocoa on tomatoes), or unapproved mixture (cocktail) of pesticides (NPAS, 2012; Horna et al., 2007; Dari et al., 2016) and stir pesticides with bare hands (Okoffo et al., 2016). A survey conducted in tomato growing communities of the Asante Akyem Agogo District of Ghana confirmed the use of non-recommended pesticides in tomato production (Obiri - Danso et al., 2011). Also, some farmers apply pesticides too close to harvesting time ignorant of or not considering pre harvest intervals, in order to sell "good looking" vegetables at the request of market women (market queens) and consumers who are mostly ignorant of the effect of its consumption (Adu-Kwateng et al., 2016; Dari et at., 2016; Ntow et al., 2006). Such fruits or vegetables are just washed with water after harvesting and sent to the market. This practice renders a greater portion of farm produce contaminated before consumption. Also, one of the most ignored precautions on pesticide application is time of reentry after pesticide application.

\subsection{Disposal}

Disposal of expired pesticides, left over solutions, water from cleaned equipment and most importantly empty pesticide containers constitute the major disposalpractices that lead to misuse (Okoffo et al., 2016; NPAS, 2012; Mattah et al., 2015; Afari-Sefa et al., 2015). With empty/used containers, most farmers dump them in the farms or bush, some bury in the farm, a few burns them while others re-use for hous ehold purposes (to keep water and other food items such as palm oil, salt or sugar among others) after washing them (Okoffo et al., 2016; NPAS, 2012; Mattah et al., 2015; Afari-Sefa et al., 2015). Most farmers dispose left over pesticides solutions and water from washed equipment in their fields while a few dispose them in a designated area on their farms (Okoffo et al., 2016; Afari-Sefa et al., 2015). The inappropriate disposal of pesticides, solution, cleaning water and containers has resulted in the accumulation of pesticide residues in the soil, underground and surface water.

\section{ABUSE PRACTICES AND ASSOCIATED EXPOSURES}

The exposure/pois oning of farmers, applicators or consumers occur in Ghana mainly through oral ingestion, dermal contact, and/or inhalation. Oral ingestion occurs accidentally, especially in children through abuse practices like storage of used or unused pesticides in the home or in used food or water containers. Others accidentally consume pesticides when they take sugar, salt, oil, water and other foods kept in used pesticide containers. Farmers and applicators again get exposed because they eat, drink water or smoke with an unwashed hand after pesticide handling or application. Consumers also get exposed largely by consuming farm produce that have pesticide residues (like fruit and vegetables), especially when farmers do not obey pre-harvest interval, spray more than the recommended dosage or exceeding the number of times a pesticide can be applied in a season and/or when pesticides are applied on crops they are not recommended for. This is very worrying situation for consumers because most of the farm produce on the local market are not tested for their pesticide residue levels before or after getting to the market. High levels of pesticide residues have been detected on cabbage, onion, cucumber, lettuce, tomatoes, okra, pepper garden eggs and pawpaw from various market centers in experimental surveys (Dariet al., 2016; Hanson et al., 2007; Hussain et al., 2002, Bempah et al., 2011; Botwe et al., 2012a; Ntow et al., 2001; Darko and Akoto, 2008, Osei-Fosu, 2014). Due to the non-observance of minimum allowable distance between water bodies and spray area, disposal abuses as well as runoffs from farms (especially on vegetable and rice farms which are close to water bodies), most water bodies are contaminated with pesticide residues which are being taken mostly by Ghanaians in rural farming communities where there is no access to treated water (Fosu - Mensah et al. 2016a, b and c). Botwe et al. (2012b) in an experiment in Ghanaian communities where pesticide abuse is rampant recorded significant levels of pesticide residues in both water and water sediments detrimental to human health. Fosu Mensah et al. (2016a; 2016b; 2016c) also detected pesticide residues above the WHO Maximum Residue Limits (MRL) in soils and water samples in cocoa farms in the country.

Most farmers or applicators in Ghana have and continue to experience dermal contact with pesticides as reported by various research works (Attabila et al., 2017; Clark et al., 1997). Dermal contact is by far the largest pathway through which pesticides enter the body of farmers and applicators. Non-use or partial use of PPEs exposes body parts of farmers and applicators to spillage during handling or loading, or leakages from knapsack sprayers during application. Others get drenched in the very solution they spray because the nozzles height may be too high or the right pattern of spraying was not followed. In most situations, the applicator's clothe collects the sprayed solution from the crop or weed during spraying while they walk through the sprayed area.

Pesticides inhalation also continues to be a challenge in Ghana. The non-use of respirators or nose 
masks during pesticide handling, loading and application predisposes a lot of applicators to the effects of inhaling pesticides. Farmers usually complain of difficulty in breathing when using respirators. The problem with using handkerchiefs as nose mask is that they are able to absorb the solution when there is drift, increasing risk of inhalation. Some applicators also use nozzles that encourage drift resulting in pesticide mists in the air. Most farms in the periurban areas do not have wind/drift break borders that would save the immediate environment from some amount of drift exposing close by populations to pesticide poising. Most chemical sellers inhale chemical fumes while they sit and even eat in their store or showrooms. Some apply pesticides that are not meant for domestic use in their homes while some others do not allow aeration in their rooms after application of pesticides. Worrying health impacts similar to those seen with pesticides misuse in the agricultural sector are being recorded in homes especially in the control of bedbugs and rodents. In July of 2016 in Kumasi, two siblings died after allegedly inhaling a substance (insecticide) that was used to control bed bugs (Ghana Web, 2016).

\section{PUBLIC HEALTH ISSUES}

Farmers and applicators are not the only individuals affected by the harms caused by the misuse of pesticides in Ghana but consumers too. Medical officers believe that some medical conditions and deaths among Ghanaians perceived to be "natural" may be related to pesticide abuse, partly because poisonings are hard to diagnose (NPAS, 2012). Pesticide pois oning may be similar to other disorders like pneumonia, asthma, heatstroke, low blood sugar or intestinal infections (Oudejans, 1991). Pesticide poisoning may be connected to a variety of human health challenges from headaches to cancer, reproductive issues, endocrine disruption, nervous system issues, skin and eye irritation, dizziness, fatigue, systemic poisoning and others which can be severe or fatal occasionally (Sarwar, 2015; Oudejans, 1991). While acute health challenges may occur immediately or a few minutes, hours or days after exposure, chronic health effects occur long after even minimal exposure to pesticides.

Overall, pesticide exposures to farmers, applicators and consumers result in accumulation of pesticide residues and they suffer the effects. For these practices, Ntow et al. (2008) revealed $88 \%$ of farmers' blood serum and $75 \%$ of human breastmilk contained high levels of pesticide residues.
Daily intake of DDTs and HCHs for infants from human breastmilk were above the threshold compared with the guidelines as proposed by health Canada. Numerous other studies have also detected levels of pesticide contamination on farmers in Ghana, reviling that some farmers have accumulated pesticides residue at levels above the tolerable daily intake limit in their blood and breastmilk. This adversely affect their health as well the health and development of their lactating babies (NPAS, 2012; Ntow, 2001; Ntow et al., 2008; Asante and Ntow, 2009). In 2008, Ntow reported on a work carried out in 2005 which revealed that farmers with these high levels of pesticide residue had been exposed to pesticides for between $1-26$ year(s) (Ntow et al., 2008). This implies that children belonging to farmer households who were fed with contaminated milk would be at least 25 years or below by the time of the research. Thirteen years on in 2018 makes children belonging to farmer households who were fed with such contaminated breast milk 38 years or below, and may be susceptible to the repercussions of the contamination. Some pesticide residues that have been detected in food, water, water sediment, air, blood and human breastmilk at significant levels are listed in Table 1. Table 2 also summarizes the possible symptom(s) seen with poisoning from some active ingredients of pesticides registered in the country.

\section{PESTICIDE USE AND HEALTHCARE IN GHANA}

In Ghana, one limitation that has made the recognition of pesticide poisoning a challenge is the fact that medical practitioners have mostly been left out of pesticide misuse issues as well as the fight against its effects on humans. Generally, there is a weak linkage between the occupation of individuals, the clinical symptoms they report at healthcare facilities and the diagnosis and treatment they receive, especially in the rural areas. Training health workers in the safe handling, identification and management of pesticide poisoning at all health posts will be of great help to the country. Involving healthcare practitioners in pesticide abuse is sues and organizing special sensitization programmes for them would strengthen their ability to perfectly link farmers' history on pesticide use with clinical symptoms they present at health care facilities to ensure proper diagnosis and treatment. This would help to reduce the effect of exposures they (Farmers) undergo. 
Table 1: list of some pesticides detected in food and water in Ghana and their levels

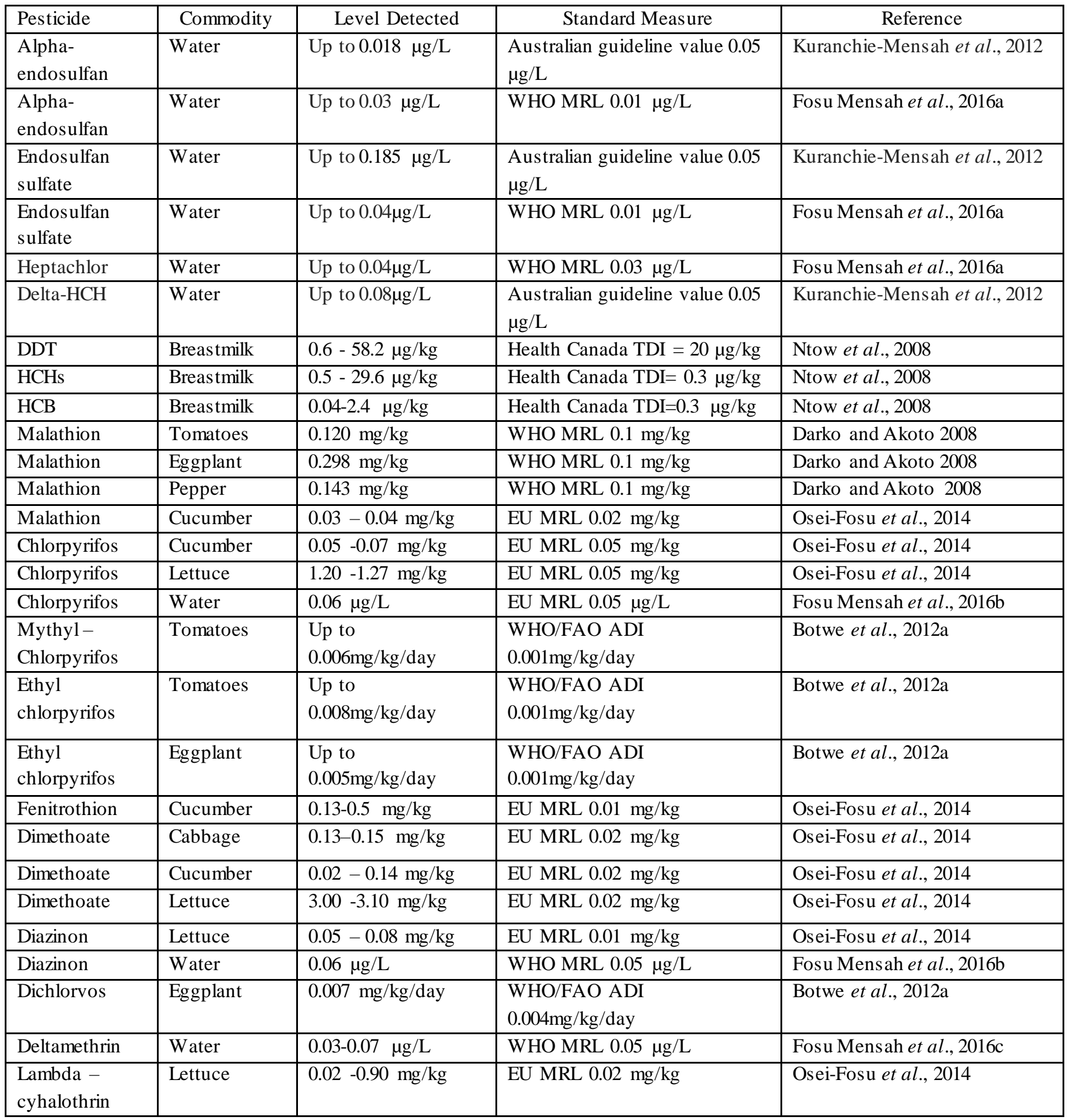

TDI = Health Canada Tolerable Daily Intake, ADI = Acceptable Daily Intake 
Table 2. Some active ingredients of pesticides registered in the country and their poisoning symptoms

\begin{tabular}{|c|c|c|c|}
\hline Group & Active ingredient used in Ghana & Symptoms & Reference \\
\hline Pyrethriods & $\begin{array}{l}\text { Permethrin, Cypermethrin, } \\
\text { Fenvalerate, Lambda-cyhalothrin }\end{array}$ & $\begin{array}{l}\text { Fine tremor, reflex hyperexcitability, salivation, choreoathetosis, abnormal facial } \\
\text { sensation, dizziness, headache, fatigue, vomiting, diarrhea and irritability to sound and } \\
\text { touch, pulmonary edema, muscle fasiculations, seizures and coma }\end{array}$ & $\begin{array}{l}\text { Roberts and } \\
\text { Reigart, 2013; Goel } \\
\text { and Aggarwal, } \\
2007\end{array}$ \\
\hline $\begin{array}{l}\text { Organophosph } \\
\text { ates (OPs) }\end{array}$ & $\begin{array}{l}\text { Chlorpyrifos, diazinon, } \\
\text { fenithrothion, dimethoate, } \\
\text { malathion, methyl parathion } \\
\text { (baned), }\end{array}$ & $\begin{array}{l}\text { Early symptoms: headache, nausea, dizziness, sweating, lacrimation, salivation and } \\
\text { rhinorrhea. Worsening symptoms: muscle twitching, weakness, tremor, incoordination, } \\
\text { vomiting, abdominal cramps and diarrhea. Blurred/dark vision, restlessness, memory } \\
\text { loss, confusion and depression, bizarre behavior resembling alcohol intoxication. In } \\
\text { children: bradycardia, muscular fasciculations, lacrimation, sweating, Seizures, } \\
\text { lethargy and coma. }\end{array}$ & $\begin{array}{l}\text { Roberts and } \\
\text { Reigart, 2013; } \\
\text { Goel and } \\
\text { Aggarwal, } 2007\end{array}$ \\
\hline Carbamates & Carbofuran, Carbendazim, & $\begin{array}{l}\text { Malaise, muscle weakness, dizziness, constricted pupils, salivation, slobbering, profuse } \\
\text { sweating, incoordination, muscle twitching and slurred speech. Headache, nausea, } \\
\text { vomiting, abdominal pain, and diarrhea. Transient hyperbilirubinemia may occur. Acute } \\
\text { pancreatitis, coma, seizures, hypotonicity, hypertension and cardiorespiratory } \\
\text { depression. }\end{array}$ & $\begin{array}{l}\text { Roberts and } \\
\text { Reigart, 2013; Goel } \\
\text { and Aggarwal, } \\
2007\end{array}$ \\
\hline $\begin{array}{l}\text { Dipyridilium } \\
\text { or Bipyridyl }\end{array}$ & Paraquat & $\begin{array}{l}\text { Localized injury to tissues of contact skin, hands may become dry and fissured, } \\
\text { horizontal ridging of the fingernails. Chronic exposure causes loss of fingernails. } \\
\text { Ingestion: Severe inflammation, burns and ulceration of the tongue, oral mucosa and } \\
\text { throat, corrosive injury to the gastrointestinal tract, renal tubular necrosis, hepatic } \\
\text { necrosis and pulmonary fibrosis, haemorrhagic pulmonary oedema or acute respiratory } \\
\text { distress syndrome (ARDS). Moderate poisoning: Vomiting, diarrhoea and dysphagia, } \\
\text { followed by mild renal tubular damage with respiratory symptoms (cough, } \\
\text { breathlessness and pulmonary opacities), death. Severe poisoning: Ulceration and } \\
\text { multi-organ dysfunction. Respiratory problems, renal failure, metabolic acidosis, } \\
\text { hepatocellular damage and death. }\end{array}$ & $\begin{array}{l}\text { Roberts and } \\
\text { Reigart, 2013; Goel } \\
\text { and Aggarwal, } \\
2007\end{array}$ \\
\hline $\begin{array}{l}\text { Chlorophenox } \\
\text { yacetic } \\
\text { herbicides }\end{array}$ & $\begin{array}{l}\text { 2,4-D } \\
\text { (2,4dichlorophenoxyacetic acid) }\end{array}$ & $\begin{array}{l}\text { Ingestion: Burning, nausea, vomiting, facial flushing and profuse sweating. In large } \\
\text { quantities: headache, dizziness, muscle weakness, depression, coma, rhabdomyolysis } \\
\text { and respiratory distress. Renal injury produces oliguria and proteinuria. }\end{array}$ & $\begin{array}{l}\text { Roberts and } \\
\text { Reigart, 2013; Goel } \\
\text { and Aggarwal, } \\
2007\end{array}$ \\
\hline $\begin{array}{l}\text { Phosphonate } \\
\text { herbicides }\end{array}$ & Glyphosate & $\begin{array}{l}\text { Mouth and throat pain, nausea, vomiting, diarrhea and abdominal discomfort. Oral } \\
\text { exposures: Tachypnea, dysrhythmias, hypotension, non-cardiogenic pulmonary edema, } \\
\text { hypovolemic shock, oliguria and respiratory failure. Seizures and depression. }\end{array}$ & $\begin{array}{l}\text { Roberts and } \\
\text { Reigart, } 2013\end{array}$ \\
\hline
\end{tabular}




\section{WEAK MONITORING AND ENFORCEMENT SYSTEMS}

There are excellent mechanisms in place to ensure the regulation of pesticide sale and use in the country. As part of its objectives, the Environmental Protection Agency of Ghana is responsible for the implementation of environmental policies and ensure that planning is integrated and consistent with the country's desire for effective and long-term maintenance of environmental quality. It also ensures that there is an environmentally sound and efficient use of both renewable and nonrenewable resources in the process of national development. It also has to guide development to prevent, reduce, and as far as possible, eliminate pollution and actions that lower the quality of life. Again, it has to apply legal processes in a fair, equitable manner to ensure responsible environmental behaviour in the country, among others. However, the body lacks the human resource to embark on regular monitoring of pesticide sale and use. The Ministry of Food and Agriculture (MoFA) has the Plant Protection and Regulatory Services Directorate (PPRSD) and is mandated through the Pesticide and Fertilizer Regulatory Division Act 803 (2010) to compliment the Ghana EPA to supervise and train pesticide inspectors, register and inspect pesticide dealers and provide information materials and training on pesticides, among others, for retailers and farmers. Also, to tackle illegal pesticides trade, the Ghana Revenue Authority's Customs Division is mandated under Act 791 (2009) to regulate all imports into Ghana including chemicals (Kwakye et al. 2018). Under the auspices of the Ghana EPA, the customs division examines documents and certificates issued by the Ghana EPA to validate the claim of the bearer regarding a particular importation. The law (Act 791) gives customs officers the jurisdiction to search for certain persons, premises and baggage and seize prohibited items, including pesticides (Kwakye et al. 2018). The Food and Drugs Authority of Ghana as part of its mandate must ensure the safety and wholesomeness of food; and also ensures that household chemicals (including pesticides) are safe and effective. There seem to be no or weak systematic routine test on foods available in the Ghanaian market for pesticide residue by the appropriate governmental regulatory body (NPAS, 2012). Even though testing for pesticide residues on export crops such as cocoa is routine and stringent, such stringency is seemingly not applied when it comes to food produced and consumed locally. This is partly because there seems to be a lack of clarity over the exact governmental agency responsible for conducting such tests. Farmers involved in export - oriented cash crop production are usually trained in Good Agricultural Practices (GAP) and safe use of pesticides but those who produce for the domestic market are usually left out. Under Act 528 (1996), incorporated in Section II of the EPA Act 490 of 1994, it is required that all stakeholders including importers, dealers, applicators and transporters are licensed. The Act states that importation, formulation and manufacturing, distribution or sale, and commercial application and transportation are the key activities under pesticide management; and lists bulk storage and disposal of pesticide waste and containers as other activities (EPA, 2012). Currently, there exis $t$ unregistered pesticide dealers (NPAS, 2012), unregistered and banned pesticides are in the hands of farmers and on the shelves of dealers (Afari-Sefa et al., 2015; Dari et al., 2016), unregistered applicators, transporters and distributors, and improper disposal of pesticide waste and containers. Kwakye et al. (2018) after a survey on the pesticides policy implementation in Ghana concluded that the implementation has not adequately dealt with non-state actors like pesticide importers, dealers' and farmers with respect to the choice of particular pesticides for a given problem, technical knowledge on field diagnosis of pests and diseases, professionally dispensing pesticides to farmers, the use of PPEs. State actors on the pesticides policy implementation also have challenge with availability of pesticide user manuals to be effectively used by pesticide dealers, lack of accredited laboratory to test the quality of pesticide products, the lack of financial benefits and bonuses, inadequate inspectors assigned to dealers and users of pesticides, and inadequate transportation facilities to easily access pesticide dealers and users (Kwakye et al. 2018).

\section{PESTICIDES REGISTERED IN GHANA FROM 2010 - 2015}

Ghana's Environmental Protection Act requires that pesticides are classified as for general use, restricted use, suspended or banned. A pesticide may be classified as suspended or restricted if its application may have unreasonable effects on humans, animals or the environment. Ghana's number of registered pesticides continues to rise and currently has almost 540 registered pesticides and 32 banned pesticides (Fig. 1.0). All banned pesticides are within the insecticide groups, which also constitute the largest group of pesticides registered for use in the country, followed by herbicides then fungicides. Plant growth regulators, molluscicides, rodenticides, nematicides and adjuvants 
constitute the other few pesticides registered for use in

Ghana.

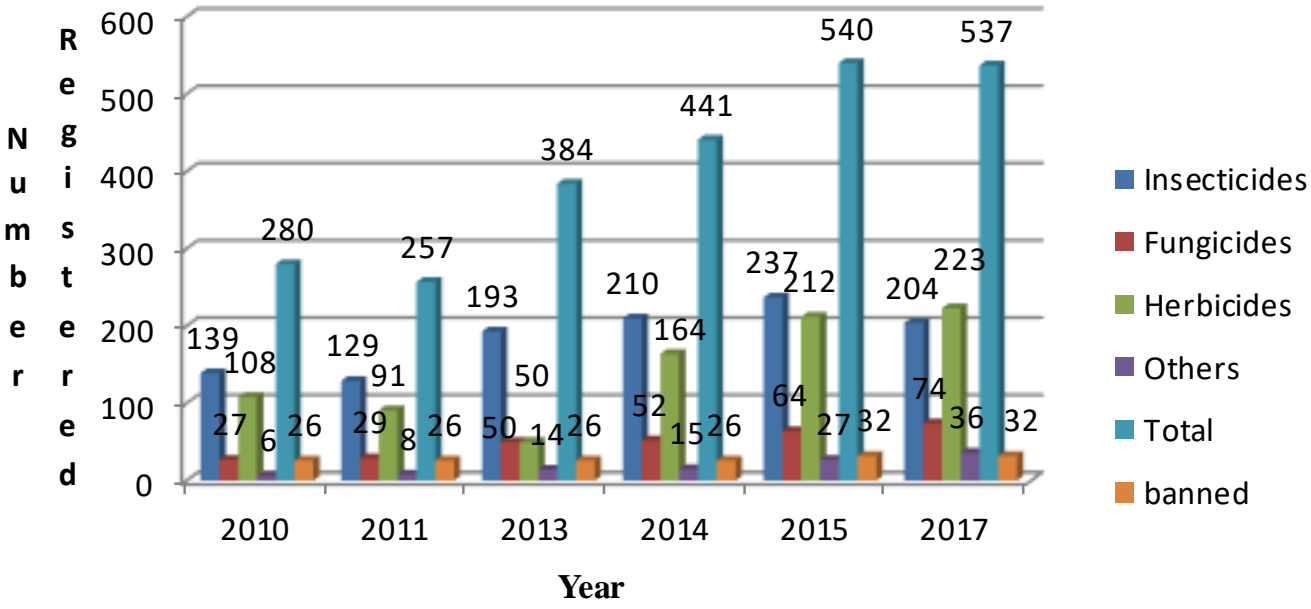

Fig.1. Ghana's pesticides registration trends from 2010 - 2017

\section{CONCLUSION}

It is evidently clear that pesticide abuse is common in Ghana and occurs from pesticides handling through usage to disposal. To minimize abuse and its consequentialeffects on human and the environment, there is the need for regular public awareness creation, strong linkage between pesticide use and healthcare, a reduced reliance on pesticides use through adoption of integrated pest management (IPM) systems. Research is needed in developing inexpensive PPEs suitable to for use by tropical farmers as well as innovative ways of collecting pesticide wastes to prevent pollution. It is also prudent that national agencies responsible for the monitoring and enforcement of legislation on pesticide sale and use are empowered to ensure a strict adherence to the rules and make the environment safe for now and generations to come.

\section{ACKNOWLEDMENT}

The authors are grateful to the KAFACI - Young Scientist Pilot Research Project for the support in getting this document together.

\section{REFERENCES}

[1] Adu-Kwarteng, E., Bortey, H.M., Aidoo, A. \& AduAppiah, A. (2016). Postharvest Handling of tomato in Africa: Reduce postharvest losses to increase food availability in Africa. Published by National Institute of
Horticultural and Herbal Sciences, Rural Development Administration, Rep. of Korea. ISBN 978-89-4804282-5 93520; pp71- 84

[2] Afari-Sefa V., Asare-Bediako E., Kenyon L., \&Micah, J.A. (2015). Pesticide use practices and perceptions of vegetable farmers in the cocoa belts of the Ashantiand Western Regions of Ghana. Adv Crop Sci Tech 3: 174. doi:10.4172/2329-8863.1000174

[3] Asante, K. A. A., \& Ntow, W. J. (2009). Status of Environmental Contamination in Ghana, the perspective of a Research Scientist. Interdisciplinary Studies on Environmental Chemistry - Environmental Research in Asia, Eds., Y. Obayashi, T. Isobe, A. Subramanian, S. Suzuki and S. Tanabe, 253-260.

[4] Attabila, A., Phung, D. T., Hogarh, J. N., Osei-Fosu, P., Sadler, R., Connell, D., \& Chu, C. (2017). Dermal exposure of applicators to chlorpyrifos on rice farms in Ghana. Chemosphere, 178, 350-358.

[5] Bempah, C. K., Donkor, A. K., Yeboah, P. O., Dubey, B., \&Osei- Fosu, P. (2011). A preliminary assessment of consumer's exposure to organochlorinepesticides in fruits and vegetables and the potential health risk in Accra Metropolis. Ghana Food Chemistry, 128,10581065.

[6] Botwe, B. O., Ntow, W. J., Nyarko, E., \& Kelderman, P. (2012a). Evaluation of occupational and vegetable dietary exposures to current-use agricultural pesticides 
in Ghana. Pesticides-recent trends in pesticide residue assay. In Tech, 46-62.

[7] Botwe, B. O., Ntow, W. J., \& Nyarko, E. (2012b). Pesticide contamination in groundwater and streams draining vegetable plantations in the Ofinso District, Ghana. In Soil Health and Land Use Management. Intech Open.

[8] Clarke, E.E.K., Levy, L.S., Spurgeon, A., \& Calvert, I.A. (1997). The problems associated pesticide use by irrigation workers in Ghana. Occupational Medicine 47, 301- 308

[9] Dari, L., Addo, A., \& Dzisi, K. A. (2016). Pesticide use in the production of Tomato (Solanum lycopersicum L.) in some areas of Northern Ghana. African Journal of Agricultural Research - Academic Journals, 11(5), 352-355. http://doi.org/10.5897/AJAR2015.10325

[10] Darko, G. and Akoto, O. (2008). 'Dietary intake of organophosphorus pesticide residues through vegetables from Kumasi, Ghana', Food and Chemical Toxicology, 46 (12), pp3703-3706

[11] Dinham, B. (2003). Growing vegetables in developing countries for local urban populations and export markets: problems confronting small-scale producers. Pest Management Science 59: 575-582.

[12] EPA. (2012). Pesticide registration manual. Accra: Environmental Protection Agency Ghana

[13] Fosu-Mensah, B. Y., Okoffo, E. D., Darko, G., \& Gordon, C. (2016a). Assessment oforganochlorine pesticide residues in soils and drinking water sources from cocoa farms in Ghana. SpringerPlus, 5(869). http://dx.doi.org/10.1186/s40064- 016-2352-9.

[14] Fosu-Mensah, B. Y., Okoffo, E. D., Darko, G., \& Gordon, C. (2016b). Organophosphorus pesticide residues in soils and drinking water sources from cocoa producing areas in Ghana. Environmental Systems Research, 5(10). http:// dx.doi.org/10.1186/s40068016-0063-4.

[15] Fosu-Mensah, B. Y., Okoffo, E. D., \& Mensah, M. (2016c). Synthetic pyrethroids pesticide residues in soils and drinking water sources from cocoa farms in Ghana. Environment and Pollution, 5(1), 60e72. http://dx.doi.org/10.5539/ ep.v5n1p60

[16] Ghana Web (22nd July, 2016). Kumasi twins who died inhaling insecticide spray buried https://www.ghanaweb.com/GhanaHomePage/NewsA rchive/Kumasi-twins-who-died-inhaling-insecticidespray-buried-457288\#
[17] Goel, A., \& Aggarwal, P. (2007). Pesticide poisoning. National medical journal of India,20(4), 182.

[18] Hanson, R., Dodoo D. K., \& Essumang D. K. (2007). The effect of some selected pesticides on the growth and reproduction of fresh water Oreochromis niloticus, Chrysicthys nigrodigitatus and Clarias griepings. Bull. Environ. Contam. Toxicol. 79:544-547.

[19] Horna, D., Smale, M., Al-Hassan, R., Falck-Zepeda, J., \& Timpo, S. E. (2008). Insecticide use on vegetables in Ghana: would GM seed benefit farmers? Intl Food Policy Res Inst. Available online: http://www.ageconsearch.umn.edu/bitstream/6506/2/ 462466.pdf (accessed on 20 September 2016).

[20] Hussain, S., Masud, T., \& Ahad, K. (2002). Determination of pesticides residues in selected varieties of mango. Pak. J. Nutr, 1(1), 41-42.

[21] Kuranchie-Mensah, H., Atiemo, S. M., Palm, L. M. N. D., Blankson-Arthur, S., Tutu, A. O., \& Fosu, P. (2012). Determination of organochlorine pesticide residue in sediment and water from the Densu river basin, Ghana. Chemosphere, 86(3), 286-292.

[22] Kwakye, M. O., Mengistie, B., Ofosu-Anim, J., Nuer, A. T. K., \& Van den Brink, P. J. (2018). Pesticide registration, distribution and use practices in Ghana. Environment, Development and Sustainability, $1-25$.

[23] Mattah, M. M., Mattah, P. A. D., \& Futagbi, G. (2015). Pesticide application among Farmers in the catchment of Ashaiman Irrigation Scheme of Ghana: Health Implications. Journal of Environmental and Public Health, 2015(547272), 1-7. http://doi.org/10.1155/2015/547272

[24] NPAS (2012). PESTICIDE CRISIS: The need for further Government action. Northern Presbyterian Agricultural Services, Christian Aid, (April 2012). Retrieved 12/08/2016 from https://www.christianaid.org.uk/images/ghanas pesticide-crisis.pdf

[25] Ntow, W.J. (2001). Organochlorine pesticides in water, sediment, crops, and human fluids in a farming community in Ghana. Archives of Environmental Contamination and Toxicology, 40, pp: 557-563.

[26] Ntow, W.J., Gijzen, H.J., Kelderman, P., \& Drechsel, P. (2006). Farmer perceptions and pesticide use practices in vegetable production in Ghana. Pest. Manage. Sci. 62 (4), 356-365. 
[27] Ntow, W. J., Tagoe, L. M., Drechsel, P., Kelderman, P., Gijzen, H. J., \& Nyarko, E. (2008).

[28] Accumulation of persistent organochlorine contaminants in milk and serum of farmers from Ghana. Environmental research, 106(1), 17-26.

[29] Obiri-Danso, K., Adonadaga, M. G., \& Hogarh, J. N. (2011). Effect of agrochemical use on the drinking water quality of Agogo, a tomato growing community in Ashanti Akim, Ghana. Bulletin of environmental contamination and toxicology, 86(1), 71-77.

[30] Okoffo, E. D., Mensah, M., Yayra, B., \& Mensah, F. (2016). Pesticides exposure and the use of personal protective equipment by cocoa farmers in Ghana. Environmental Systems Research, 5(17). http://doi.org/10.1186/s40068-016-0068-z

[31] Osei-Fosu, P., Donkor, A. K., Nyarko, S., Nazzah, N. K., Asante, I. K., Kingsford-Adabo, R., \& Arkorful, N. A. (2014). Monitoring of pesticide residues of five notable vegetables at Agbogbloshie market in Accra,

Ghana. Environmental monitoring and assessment, $\quad$ 186(11), 7157-7163. http://doi.org/10.1007/s 10661-014-3917-0

[32] Oudejans, J. H. (1991). Agro-pesticides: properties and functions in integrated crop protection. Economic and Social Commission for Asia and the Pacific (ESCAP) Secretariat, United Nations, Bangkok

[33] Roberts, J. R., \& Reigart, J. R. (2013). Recognition and management of pesticide poisonings.

http://www2.epa.gov/pesticide-worker-safety

[34] Sarwar, M. (2015). The dangers of pesticides as sociated with public health and preventing of the risks. International Journal of Bioinformatics and Biomedical Engineering, 1(2), 130-136.WHO (2004). Childhood Pesticide Poisoning: Information for advocacy and action, May 2004, 7

[35] WHO (2008). Pesticides: Children's Health and the Environment, WHO Training Package for the Health Sector, World Health Organization, July 2008 version. Retrieved 20/09/2016 from http://www.who.int/ceh/capacity/Pesticides.pdf 